\title{
Multi-Didaxis in the Drama of Lope de Vega and Sor Juana Inés de la Cruz
}

\section{Parameters of a Poly-Contextural Literary Theory}

In his essay “The Return to Philology,” Edward Said pleads for a new kind of comparative reading. He argues that in order to do justice to the complexity of texts, comparative literature specialists should "move from the specific to the general both integratively and synthetically[,]" by gradually locating the texts in their times "as part of a whole network of relationships [...]." Indeed, traditionalWestern as well as non-Western-literary theories normally are unsuitable for such programme. Relying mostly on binary, mono-systematic premises reduces too much of the empirical complexity of a polycentric world, stressing either the affinities and similarities, or the differences which exist between diverse literary cultures.

In order to dissolve these problems and to construct a more complex theory of culture as a dynamic net, I suggest resorting to the poly-contextural theory of Gotthard Günther. In his text "Life as Poly-Contexturality,"2 he develops a multi-valued logic which has two main advantages. First, it allows taking into account several referential systems at the same time. The world can be conceived of as a universal structure consisting of several interacting, overlapping nets, ${ }^{3}$ and every single perspective as a superimposition of various perspectives. And second, it makes it possible to consider the cultural location of observers without completely identifying them with a certain context. By bearing in mind also graded differences between several observers, the setting allows for the consideration of the exact gradation Edward Said speaks of.

The recourse to poly-contextural theory allows the multi-directional circulation of conceptual and material forms to be taken into account without neglecting

1 Edward W. Said, Humanism and Democratic Criticism (New York, NY: Columbia University Press, 2004), pp. 57-84, p. $61 \mathrm{f}$.

2 See Gotthard Günther, "Life as Poly-Contexturality," in: Helmut Fahrenbach, ed., Wirklichkeit und Reflexion: Walter Schulz zum 60. Geburtstag (Pfullingen: Neske, 1973), pp. 187-210, online version: http://www.vordenker.de/ggphilosophy/gg_life_as_polycontexturality.pdf (retrieved: 28 October 2014).

3 See p. 5 of the online-version: "the number of [...] contexturalities which crisscross this universe is enormous." 
the concrete "location of culture" (Bhabha), which should be borne in mind since it plays a particularly important role in the hierarchical colonial interactions of cultures. $^{4}$

Applied to a theory of textuality, ${ }^{5}$ the poly-contextural logic provides a set of new interpretive and comparative methods. ${ }^{6}$ If we conceive the authors of the texts as poly-contextural subjects and the texts themselves as networks of several interwoven sub-systems, we can consider new forms of cultural belonging and of multi-directionality. One important aspect, which until now has mostly been neglected, is the textual capacity to pursue several pragmatic aims at the same time by spreading them over diverse textual layers or "stages."7

In the case of dramatic texts, this complexity is even more fascinating. Aimed at being performed, they can be re-conceived of as semiotic systems that model, enact and evoke a (potentially) poly-contextural world: a single performance is always bound to a concrete (cultural) hic et nunc but can, at the same time, depart from this in various ways by means of sheer textuality. This potential superimposition enables the creation of a wide range of combinations of propaganda and critical transgression. The drama can address a present diversified audience (social class, cultural background, gender, etc.) and extend its range into imagined universal contexts concurrently. This allows the authors to take complex stands with regard to their own and to other cultures. They can combine propaganda, critical negotiation (Greenblatt) ${ }^{8}$ and even transgression in the most varied ways. As the genre can be seen as an institutionalised social mass medium, I propose to refer to this potential to reach several audiences in a different way as its multi-didaxis.

In the following, I wish to show how this new theoretical framework is capable of giving new insights into the theatre culture of the Spanish and Hispanic American Golden Age. A comparison of Fuenteovejuna by Lope de Vega and

\footnotetext{
4 For more detail see Barbara Ventarola, "Weltliteratur(en) im Dialog: $\mathrm{Zu}$ einer möglichen Osmose zwischen Systemtheorie und postkolonialen Theorien,” in: Mario Grizelj and Daniela Kirschstein, edd., Riskante Kontakte: Postkoloniale Theorien und Systemtheorie? (Berlin: Kadmos, 2014), pp. 161-196.

5 Sheldon Pollock states that literary theory is foremost a "theory of textuality as well as the history of textualized meaning." ("Future Philology? The Fate of a Soft Science in a Hard World," Critical Inquiry 35 [2009], pp. 931-961, p. 934).

6 A detailed presentation of my new theory of textuality and of literary interpretation can be found in Ventarola, Transkategoriale Philologie: Liminales und poly-systematisches Denken bei Gottfried Wilhelm Leibniz und Marcel Proust (Berlin: Schmidt, 2015), chap. 3, pp. 124-288.

7 See chap. 3.3.

8 For the concept of drama as negotiation see Stephen Greenblatt, Shakespearean Negotiations: The Circulation of Social Energy in Renaissance England (Berkeley, CA: University of California Press, 1988).
} 
El divino Narciso (The Divine Narcissus) by Sor Juana Inés de la Cruz will make it possible to shed new light on the ambiguities of their texts, as well as of the cultural relationship they have with each other. I will start with Fuenteovejuna.

\section{Lope de Vega: The Ambivalent Murder of the Tyrant in Fuenteovejuna (1619)}

Fuenteovejuna is undoubtedly the most famous play by this extremely prolific author. Printed in 1619, ten years after his pathbreaking Arte nuevo de hacer comedias (New Art of Writing Plays), the drama is a perfect realisation of central precepts of Lope's new dramatic theory. The Aristotelian unities are partially cancelled, ${ }^{9}$ the comic and the tragic are merged, ${ }^{10}$ the language is differentiated in sociolects ${ }^{11}$ and-above all-the focus is set on the populace. ${ }^{12}$ The drama stages a true story, the rebellion of a small peasant community against their lord, which culminates in his assassination. ${ }^{13}$ In accordance with the Arte nuevo, the populace is the protagonist as well as the main addressee of the theatrical performance.

Because of its innumerable ambivalences, the drama has provoked conflicting and even opposing interpretations. ${ }^{14}$ The main question is whether the

9 See Félix Lope de Vega y Carpio, El arte nuevo de hacer comedias en este tiempo [1609], ed. Juana de José Prades (Madrid: Consejo Superior de Investigaciones Científicas, 1971), pp. 275328, vv. $188 \mathrm{ff}$.

10 Vv. $174 \mathrm{ff}$.

11 Vv. 264 ff., vv. $305 \mathrm{ff}$.

12 Vv. 9 f., vv. $47 \mathrm{ff}$.

13 For the real incidents that Lope has woven together see Roberto González Echevarría, "Introduction,” in: Lope de Vega, Fuenteovejuna [1619], trans. Gregary Joseph Racz (New Haven, CN: Yale University Press, 2010), pp. XIV ff. See also Joachim Küpper, "Lope de Vega: Fuente Ovejuna," in: Volker Roloff and Harald Wentzlaff-Eggebert, edd., Das spanische Theater: Vom Mittelalter bis zur Gegenwart (Düsseldorf: Schwann Bagel, 1988), pp. 105-122.

14 A detailed and still instructive research report can be found in Teresa J. Kirschner, "Evolución de la crítica de Fuenteovejuna, de Lope de Vega, en el siglo XX," Cuadernos hispanoamericanos 320/321 (1977), pp. 450-465. See also Eberhard Müller-Bochat, ed., Lope de Vega (Darmstadt: Wissenschaftliche Buchgesellschaft, 1975). For more recent research see Küpper, "Fuente Ovejuna"; Manuel Villegas Ruiz, Fuenteovejuna: El drama y la historia (Baena: Delegación de Cultura, Excma. Diputación Provincial, 1990); DeLys Ostlund, The Re-Creation of History in the Fernando and Isabel Plays of Lope de Vega (New York, NY: Peter Lang, 1997); Malveena McKendrick, Playing the King: Lope de Vega and the Limits of Conformity (London: Tamesis, 2000); Elizabeth R. Wright, Pilgrimage to Patronage: Lope de Vega and the Court of Philip III, 1598-1621 (Lewisburg, PA: Bucknell University Press, 2001). 
assassination is condoned or not. In the first case, the play would call for resistance, in the second for passive obedience. Using binaristic and mono-systematic interpretative theories, one is compelled to decide for one of the alternatives. But since we can find indications for both perspectives in the text, neither is completely convincing. For this reason, I suggest applying the concept of poly-contexturality and to search for multi-didactical structures.

The most important structural pattern of the baroque comedy is the syntagmatic triad of order, disturbance of the order and its restoration after eliminating the disturbing element. On the highest level of meaning, Fuenteovejuna points to the peasant community as the disturbing element. In the scene which stages the assassination, ${ }^{15}$ the populace is depicted as an outrageous, uncontrolled and even bloodthirsty crowd: "FLORES: ¡El pueblo junto viene! / JUAN [Roxo]: [Dentro.] ¡Rompe, derriba, hunde, quema, abrasa! / ORTUÑo: Un popular motín mal se detiene." "[Flo.: They to a man rebel! / JuAn: (Offstage) Now burn and raze the place! We'll not retreat! / ORT.: These popular revolts are hard to quell.”] ${ }^{17}$ It is very likely, though, that the teachings of the play-in accordance with the prevailing ideology of the time, the Counter-Reformation-aim at controlling this danger. ${ }^{18}$

But the structural complexity of the text leads us to look further, and if we do so we can detect other, deeper levels of meaning, which make it more difficult to locate the play in its historical context. A deeper inquiry into the plot reveals a precisely composed shifting of responsibility. In the course of the play, the culpability for the escalation of violence is assigned more and more to the powerful nobleman himself. It is he who is revealed as the real disturbing element because he is depicted ever more as a tyrant. Lope achieves this aim by constructing a perfect climax, which starts right in the first scene and harmonises the macroand the micropolitics. Thus, it is true that at the beginning the inhabitants of Fuente Ovejuna welcome their lord cordially, ${ }^{19}$ a fact that could be read as proof of his blamelessness. ${ }^{20}$ But this idyllic situation soon turns out to be the mere contrasting backdrop against which the tyrannical wrongdoings of the comendador

15 Lope de Vega, Fuente Ovejuna [1619], ed. Juan María Marín Martínez, $20^{\text {th }}$ ed. (Madrid: Cátedra, 2001), vv. $1851 \mathrm{ff}$. All references to Lope's play are to this edition.

16 Vv. 1857-1859. See also vv. 1890 ff., vv. 1951 f. ("la mayor crueldad / que se ha visto entre las gentes”), v. 1977 (“con furia impaciente”).

17 Quotations from the English translation are from Lope de Vega, Fuenteovejuna, trans. G. J. Racz.

18 See the interpretation of Küpper, "Fuente Ovejuna."

19 Lope de Vega, Fuente Ovejuna, vv. 530 ff.

20 See Küpper, “Fuente Ovejuna,” p. 108. 
become even more blatant. ${ }^{21}$ The first scene of the drama, where the comendador is inciting the Grand Master of his order to carry on a war against the Catholic Kings, fits very well into this textual construction.

After this starting point, the unmasking of the comendador continues: the more the plot proceeds, the more he reveals himself to be a perfect epitome of the description of a tyrant given by Father Juan de Mariana. In 1598, he wrote his treatise De rege et regis institutione, in which he undertook to define the limits and controls on royal power:

Es propio de un buen rey defender la inocencia, reprimir la maldad, salvar á los que peligran, procurar á la república la felicidad y todo género de bienes; mas no del tirano, que hace consistir su mayor poder en poder entregarse desenfrenadamente á sus pasiones, que no cree indecorosa maldad alguna, que comete todo género de crímenes, destruye la hacienda de los poderosos, viola la castidad, mata á los buenos, y llega al fin de su vida sin que haya una sola acción vil á que no se haya entregado. Es además el rey humilde, tratable, accesible, amigo de vivir bajo el mismo derecho que sus conciudadanos; y el tirano, desconfiado, medroso, amigo de aterrar con el aparato de su fuerza y su fortuna, con la severidad de las costumbres, con la crueldad de los juicios dictados por sus sangrientos tribunales. ${ }^{22}$

Lope clearly transfers this logic to a lower level of the social hierarchy, the relationship between a feudal lord and his peasant subjects. The comendador systematically commits all the above-mentioned "crimes" and thus violates all the duties he has towards his subjects. He rapes all the women of the community or tries to

21 On closer inspection, this scene already points toward Lope's attempt to partially excuse the crowd. If at the outset of the plot the peasants welcome their sovereign with joy and delight, they are obviously willing to adapt themselves to the existing order. So the reason for their transformation must lie elsewhere; and Lope does not fail to name this reason immediately, because right after this scene, the comendador commits his first tyrannical acts (see Lope de Vega, Fuente Ovejuna, vv. 545 ff., vv. 595 ff., v. 617, vv. 621 ff., etc.).

22 Juan de Mariana, Del rey y de la institución real [De rege et regis institutione, 1598], in: Obras del Padre Juan de Mariana, ed. Francisco Pí y Margall, Biblioteca de Autores Españoles, 2 vols. (Madrid: M. Rivadeneyra, 1864-1872), vol. 2, pp. 463-576, p. 477. I translate the most important passage: "[The tyrant] believes that his greatest power lies in being able to give free rein to his passions. He considers no wickedness unseemly, commits all kinds of crimes, destroys the wealth of the powerful, violates chastity, slays the good and comes to the end of his life without having neglected to perform a single vile action." It is significant that in seventeenth-century Spain this partially dissident text is written in Latin, while the orthodox treatises on power (like that of Father Rivadeneira which will be quoted later) are written in Spanish. 
do so, ${ }^{23}$ he does not respect the elders, ${ }^{24}$ he lacks clemency, ${ }^{25}$ he constantly abuses his power, ${ }^{26}$ he is unwilling to communicate ${ }^{27}$ and, what is most important, he completely refuses to respond to any advice or warnings. ${ }^{28}$ And when Esteban, the mayor of the village, names the comendador a second Nero, ${ }^{29}$ this parallel is underscored. ${ }^{30}$ By this theatrical device, the responsibility for the violence shifts from the crowd to the lord. When-after all these violations of humanity-the populace becomes outraged, loses control and refuses to pardon their lord or to accept his nobility, ${ }^{31}$ they are perfectly mirroring his own crimes and his loss of moral nobility. ${ }^{32}$ Or to put it another way: they merely follow his example. The syntagmatic structure of the text aims at partially legitimising their cruel actions.

This interpretation can be corroborated by considering the historical background of Father Mariana's treatise. By naming Nero, Lope broadens the intertextual references of the play. He obviously evokes the whole tradition of treatises on tyrannicide, which started in the antiquity with texts by Aristotle, Seneca and Cicero, continued in the Middle Ages with John of Salisbury and Thomas Aquinas and culminates in the late sixteenth century in the aforementioned treatise by Mariana. ${ }^{33}$ It is significant that all of these authors legitimise tyrannicide in special cases and that the arguments they adduce are exactly

23 See Lope de Vega, Fuente Ovejuna, for example vv. 193 f., vv. 265 ff., vv. 595 ff., vv. 617 ff., vv. 937 ff., vv. 1065 ff., vv. 1143 ff., vv. 1210 ff., vv. 1350 ff., vv. 1570 ff., vv. 21347 ff. In vv. 807 ff., Lope also criticises the loose morals of the peasant girls. But the following incidents, especially the abduction of Jacinta (vv. $1210 \mathrm{ff}$.) and the disrupting of the wedding scene (vv. $1570 \mathrm{ff}$.), make clear that in the end the girls have no alternative because they are submitted to his immoderate power. See also v. 1145.

24 Vv. $1633 \mathrm{ff}$.

25 Vv. 1670, vv. 1248 f., v. 1272, v. 1320.

26 Vv. $1140 \mathrm{ff}$.

27 Vv. $1638 \mathrm{ff}$.

28 See for example vv. 980 ff., vv. 1015 ff., vv. 1266 ff. This point is very important, because it lays the ground for the following tyrannicide. In the sixth chapter of his treatise, Mariana states that an assassination of the tyrant is necessary and legitimate if he refuses to respond satisfactorily to advice or warnings. See Mariana, Del rey y de la institución real, pp. 479-483.

29 Lope de Vega, Fuente Ovejuna, v. 2422.

30 See also v. 1176 and vv. 1183 f., where the comendador is characterised as "más que una fiera inhumano" and as a savage tiger. By comparing him to an animal, Lope suggests that the comendador has lost his status as a persona, as Baltasar Gracián conceived it in his Criticón.

31 Vv. $1883 \mathrm{ff}$.

32 One may appreciate how precise the dramaturgical construction is by comparing vv. $1015 \mathrm{ff}$. and vv. $1248 \mathrm{ff}$. on the one hand and vv. $1880 \mathrm{ff}$. on the other. In these passages, the above-mentioned mirror structure is particularly blatant.

33 An overview of this tradition can be found in Martin Honecker, Grundriß der Sozialethik (Berlin/New York, NY: De Gruyter, 1995), pp. $361 \mathrm{ff}$. 
repeated in the play, in particular the unwillingness of the tyrant to respond to advice and therefore the lack of alternatives. ${ }^{34}$ As I cannot enumerate them all, I wish to concentrate on some particular aspects.

The first point is the natural law. In the ancient and medieval tradition, tyrannicide is seen as a lawful act because the tyrant violates the natural law which prescribes that every human being has a certain dignity and deserves respect. ${ }^{35}$ On this point, the natural law of the pagan tradition and the divine law of Christianity perfectly converge. In the play, Lope evokes this argument when the peasants often claim their dignity and even their honour. So it is true that at the beginning one of the protagonists, Frondoso, refuses to fight a duel with the comendador by pointing out that a peasant is not a man of honour and therefore cannot fight duels with noblemen. ${ }^{36} \mathrm{He}$ obviously submits himself to the contemporary social theory of power ${ }^{37}$ - which erodes the fundamental Christian egalitarianism. But here, too, we must consider the dynamics of the play. Like in the above-mentioned case, this statement of Frondoso constitutes above all a starting point for a shift, in the course of which the other peasants systematically override this humility. The more the comendador disproves his congenital honour by performing dishonourable acts, the more the peasants claim honour for themselves and legitimise this reversal with the fact that in the Commander's acts there is a deep gap between innate and moral honour:

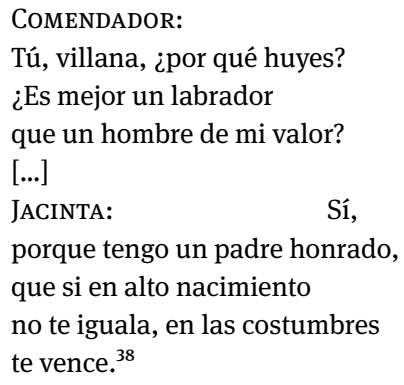

[COMMANDER: You, girl, what are you running for? / You find a clod that tills the earth / More pleasing than a man of worth? / [...]. JACINTA: Of course, / Because my father is a man / Well spoken of, though not your peer / In birth, with manners gentler still / Than any you possess.]

34 See Lope de Vega, Fuente Ovejuna, for example vv. 1248 f., vv. 1275 ff., v. 1320, v. 1670, vv. 1680 ff., vv. 1695 ff., etc.

35 See Honecker, Grundriß der Sozialethik, pp. $361 \mathrm{ff}$.

36 Lope de Vega, Fuente Ovejuna, vv. 852 f.

37 See also Küpper, “Fuente Ovejuna,” pp. 109 f.

38 Vv. 1253-1263. See also vv. 1705, v. 1815, v. 2013. 
By enacting this chiastic development, Lope inserts a hidden message into his text. He shows that, as a tyrant, the lord does not deserve to be treated as a man of honour. While the orthodox contemporary theory of power conceives hereditary rights as indefeasible, ${ }^{39}$ Lope relativises the unconditional character of these rights.

This leads to the second point: the role of women. As the ringleaders of the village hesitate over what to do, it is Laurencia, the female peasant protagonist, who makes a flaming speech reproaching their cowardice and claiming the need to restore the natural law. ${ }^{40}$ And it is only this speech that persuades them and therefore sets the elimination of the disturbing element-the lord-in motion. ${ }^{41}$ In these passages, Lope fortifies Laurencia's social role to an extent that obviously does not fit with the current orthodox conception of ideal feminine behaviour. Not only is she depicted as intelligent, eloquent and energetic, but she also intervenes actively in the public sphere and even plays a crucial role in the liberation of the village. By shaping her in this way, Lope markedly differs from the misogynist concepts of women that prevailed in his time. He obviously rejects the idea of an inherent female inferiority, which in Huarte de San Juan's essay on the education of children culminates in the didactic prescription to silence them and to keep them away from the public sphere. ${ }^{42}$

39 See for example Father Pedro de Rivadeneira's treatise on the Christian prince, Tratado de la religión y virtudes que debe tener el príncpe cristiano para gobernar y conservar sus estados, contra lo que Nicolas Maquiavelo y los políticos deste tiempo enseñan [1595], in: Obras escogidas del Padre Pedro de Rivadeneira, ed. Vicente de la Fuente, Biblioteca de Autores Españoles (Madrid: M. Rivadeneyra, 1868), pp. 449-587. See also John Neville Figgis, The Divine Right of Kings [1896] (Gloucester, MA: Smith, 1970), pp. 5 f.

40 Lope de Vega, Fuente Ovejuna, vv. 1713 ff., vv. 1750 ff.

$41 \mathrm{Vv}$. 1794ff. It is striking that this passage is replete with conceptos. A look at Lope's Arte nuevo may help to explain this peculiarity. There, Lope states that conceptos are only legitimate when they are needed for the purposes of conviction or advice (see Lope de Vega, El arte nuevo, vv. $250 \mathrm{ff}$.). This parallel shows that Laurencia is shaped even rhetorically as an important spokesperson, who is able to convince the extrafictional listeners. See also Lope de Vega, Fuente Ovejuna, vv. 1835 ff., vv. 1824 ff., vv. 1845 ff.

42 See Juan Huarte de San Juan, Examen de ingenios para las ciencias [1575], ed. Rodrigo Sanz (Madrid: Imp. La Rafa, 1930), p. 25, pp. 370 f., pp. 374 f., p. 388. A similar pattern of argumentation is used by Juan Vives (Instrucción de la mujer cristiana) and by Fray Luis de León (La perfecta casada). See Ursula Jung, Autorinnen des spanischen Barock: Weibliche Autorschaft in weltlichen und religiösen Kontexten (Heidelberg: Winter, 2010), pp. 44 ff. For more details on this topic see also Daniel Heiple, “Profeminist Reactions to Huarte’s Misogyny in Lope de Vega's La prueba de los ingenios and María de Zaya's Novelas amorosas y ejemplares,” in: Anita K. Stoll and Dawn L. Smith, edd., The Perception of Women in Spanish Theater of the Golden Age (Lewisburg, PA: Bucknell University Press, 1991), pp. 121-134. 
And what is more: in the fictional world of the play, she soon finds female imitators, so that at the end, the women form a peculiar little army to fight against the dehumanised intruder:

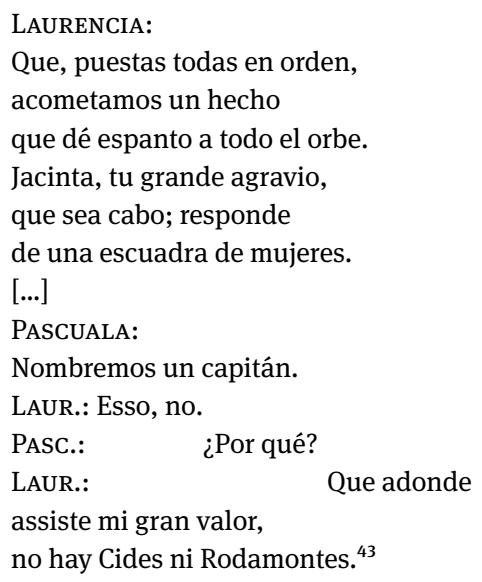

[LAUR.: Let's all of us form ordered ranks / And undertake an act so bold / We'll leave the wondering world aghast. / Jacinta, for your suffering, / I name you corporal; you're in charge / Of this brave women's squadron here. / [...] / PASc.: We'll have to name a captain, though. / LAUR.: Not true. / PASC.: How so? / LAUR.: Because who needs / El Cid or Rodomonte when / It's I who'll lead with gallantry?] ${ }^{44}$

This passage is even more striking if we look at the kind of order the women are forming. When Laurencia emphasises that they do not need a classical leader, she promulgates a kind of utopian counter-order which transcends orthodox concepts of social hierarchy.

It is well known that Lope was a close friend of María de Zayas, the most famous feminist writer of the epoch, and that together they attacked especially the misogynist postulates of Huarte de San Juan. ${ }^{45}$ In Fuenteovejuna, he obviously finds a subtle instrument to promulgate his sympathy with the current pro-feminist tendencies. Despite being a male writer in a completely patriarchal and androcentric context, he displays empathy and even sympathy for the feminist tendencies of his time.

But what about the ending of the play? At first glance, it may seem to refute the interpretation given above. The deed goes unpunished only because the Catholic

43 Lope de Vega, Fuente Ovejuna, vv. 1829-1834, vv. 1844-1847.

44 The translation is problematic because it evinces the idea of counter-order that I will speak of in the following.

45 See Heiple, “Profeminist Reactions to Huarte’s Misogyny.” 
Kings are unable to isolate the ringleaders, and they explicitly emphasise that the upheaval was unjust. ${ }^{46}$ But the irritation remains. Lope highlights that the guilty cannot be detected because, despite cruel torture, ${ }^{47}$ every member of the community refuses to betray them, namely: because the powerless stand together. ${ }^{48} \mathrm{With}$ this construction, the submission of the populace to the royal power remains ambiguous: even when the peasants repeatedly say that they want to subjugate themselves to the Kings, they resist their power; ${ }^{49}$ and it is exactly this resistance that leaves them unpunished. ${ }^{50}$ Or to put it another way: the irreverence of the populace against their Kings is not punished, but rewarded. If, on a certain level of meaning, Fuenteovejuna undoubtedly promulgates the contemporary solidarity between the populace and the king, this idea is at the same time undermined.

In addition to that, Lope carefully implies that the Kings even share responsibility for the deed. In the crucial scene where the peasants decide to assassinate the tyrant, it is explicitly said that they only take these drastic steps because the Kings are too occupied to intervene, so that the peasants have to fend for themselves: "BARRILDO: En tanto que Fernando, aquel que humilla / a tantos enemigos, otro medio / será mejor, pues no podrá, ocupado, / hazernos bien con tanta guerra en medio."51 ["BARRILDO: Before the monarchs do come, though, we will / Still need to find a remedy to meet / This enemy in that our king, who smote / So many foes, has others yet to beat." ${ }^{52}$ A closer look reveals that this passage is very ambivalent and does not necessarily fit with the alleged Platonic horizon of the play, because the absence of the Kings is ascribed to a very concrete and historically verifiable reason. ${ }^{53}$

46 Lope de Vega, Fuente Ovejuna, vv. $2442 \mathrm{ff}$.

47 We may even find some criticism of torture in the play; see vv. 2203-2205, v. 2209, vv. $2218 \mathrm{f}$.

48 Vv. 2220.

49 See vv. 1865 ff., vv. 1918 ff., vv. 2028 ff., vv. 2090 ff.

50 The clemency of the Kings may also be influenced by the fact that the lord, at the beginning of the play, tries to deceive them too. In this textual construction, the end perfectly leads back to the beginning of the play.

51 Vv. 1680-1683.

52 Again, the translation is problematic. In this case the problem comes from the fact that it elides the ambiguity of the Spanish version and transforms it into a mere praise of royal power.

53 For the Platonic interpretation of the play see especially Leo Spitzer, "A Central Theme and Its Structural Equivalent in Lope's Fuenteovejuna,” Hispanic Review 23 (1955), pp. 274-292; William C. McCrary, “Fuenteovejuna: Its Platonic Vision and Execution," Studies in Philology 58 (1961), pp. 179-192. Platonic readings of the text work on the assumption that the Catholic Kings are shaped like a distant god, which at the end appears as deus ex machina. The above-mentioned structures partially erode this interpretation. For the concrete historical background of the play see Ostlund, The Re-Creation of History, chap. 3, pp. 41-56. 
The exposed structures make it possible to enumerate a plurality of teachings of the play. Every social rank is addressed in many different ways. The (peasant) populace is first of all undoubtedly requested to respect-to a certain extent-the social hierarchy and the central moral tenets of the time. Research on Lope has demonstrated this in detail. ${ }^{54}$ But at the same time, this request is relativised, because for Lope it is only valid under a certain condition: the correct behaviour of the higher social ranks. Their members, the aristocrats in particular, have to show themselves worthy of being obeyed. They have the duty to match their congenital nobility to the nobility of their behaviour. Otherwise, they lose their right to rule. With this restriction, Lope does not completely follow the contemporary orthodox theory of power, which postulates that in every case non-resistance and passive obedience are encouraged by God. ${ }^{55}$ Instead, he revitalises the ancient and medieval tradition that is still present in the aforementioned dissident voices of his time, in order to formulate a criticism of this theory of unlimited power. In a sophisticated use of poly-intertextuality, he plays off the ancient and medieval sources against sheer contemporary orthodoxy. ${ }^{56}$ By recurring to other historical contexts, Lope is exceeding the boundaries of his own time. He is negotiating the question of power from a partially distanced standpoint where several contextures are superimposed. Propagandistic affirmation and critical assessment are realised at the same time.

So the aristocrats, too, receive a didactic message, which in a certain way is a counterpart of the message addressed to the populace. They are requested to make sure that they deserve their privileges. Both messages together include, amidst the overarching orthodoxy, a utopian impulse, since they foreshadow the

54 See for example Küpper, “Fuente Ovejuna.”

55 See for example Pedro de Rivadeneira, Tratado de la religión, pp. 452 ff. See also Figgis, The Divine Right of Kings, pp. 5 f. With this theory of social power, Rivadeneira applies the Counter-Reformation concept of divine omnipotence to earthly social structures. As Joachim Küpper has shown in his inspiring studyDiscursive Renovatio in Lope de Vega and Calderón (Berlin/Boston, MA: De Gruyter, 2017), the historical basis of the Counter-Reformation can be found in Aquinas' relativizing Augustine's concept of divine omnipotence. With my rereading of Fuenteovejuna I partially adopt a different perspective on seventeenth-century Spain.

56 The theory of power Lope is promulgating here resembles much more closely the scholastic concept of restricted power which influenced medieval feudal ideas of social order than it does Augustine's concept of divine omnipotence. For these historical interrelations see Ventarola, Kairos und Seelenheil: Textspiele der Entzeitlichung in Francesco Petrarcas Canzoniere (Stuttgart: Steiner, 2008), chap. 2 and chap. 3, pp. 34-97. 
outlines of a new social ethic where power-as for Mariana but also for Francisco Suárez-is negotiated by a social contract. ${ }^{57}$

The same is valid for the female audience. In the exemplary figure of Laurencia, the women receive two messages. On the one hand, they are requested to behave in a socially acceptable manner. Laurencia appears as a chaste woman with strong moral principles. But this precept is also relativised and completed with a utopian impulse which is transgressing the existing order because on the other hand-and, by means of the same character-women are encouraged to break their silence, to leave their passive and unconditional obedience and to fight for more social presence. They are encouraged to imitate Laurencia like the women in the play do.

Even the king is addressed in a twofold way. In the fictional figures of the Catholic Kings, he is shown as an ambivalent model. In their almost prudent and merciful actions, they are exemplary. ${ }^{58}$ But in their sharing responsibility for the cruel escalation, we might find a cautious critique of present shortcomings. It is well known that Philipp III did not care much for the peasant population and pursued his military conflicts mostly at their expense. ${ }^{59}$ In Fuenteovejuna, Lope seems to

57 In his treatise De Legibus ac Deo legislatore, Francisco Suárez develops a forward-looking theory of the monarchy as a social contract. He argues that social power always resides in the community and that its members only conditionally confer the right to exercise it on the king. See Francisco Suárez, Tractatus de Legibus ac Deo Legislatore: In Decem Libros Distributus [1613], 2 vols. (Napoli: Ex typis Fibrenianis, 1872), in particular "Liber sextus" and "Liber septimus," vol. 2, pp. 139-341. In general, Suárez's theory of contract and his importance to the development of modern legal concepts is relatively little studied within the whole of his work. I enumerate some recent studies: John Wiedhofft Gough, The Social Contract: A Critical Study of its Development, $2^{\text {nd }}$ ed. (Oxford: Clarendon Press, 1957), pp. 68-71; Daniel Schwartz, "Francisco Suárez on Consent and Political Obligation,” Vivarium 46.1 (2008), pp. 59-81; Schwartz, "Francisco Suárez y la tradición del Contrato Social," Contrastes: Revista Internacional de Filosofía 10 (2005), pp. 119-138; John Doyle, “Francisco Suárez, S.J. (1548-1617): On the Interpretation of Laws,” The Modern Schoolman 83 (2006), pp. 197-222; Martine Pécharman, "Les fondements de la notion d'unité du peuple chez Suárez," in: Yves Charles Zarka, ed., Aspects de la pensée médiévale dans la philosophie politique moderne (Paris: Presses Universitaires de France, 1999), pp. 104-126.

58 The behaviour of the Kings almost corresponds to the depiction of the good king given by Father Mariana. See Mariana, Del rey y de la institución real, pp. $477 \mathrm{f}$. Of particular importance is their reaction when the populace asks for an audience: instead of rejecting it, they lend an attentive ear to the complaints of Esteban, the mayor of the little village, and give him the opportunity to demonstrate the tyrannical character of the comendador, before they decide what to do (Lope de Vega, Fuente Ovejuna, 2380 ff.).

59 See José Maria Díez Borque, “Teatro de palacio: excesos económicos y protesta pública,” in: Alberto Blecua, Ignacio Arellano, and Guillermo Serés, edd., El teatro del Siglo de Oro: Edición e interpretación (Madrid: Iberoamericana; Frankfurt a.M.: Vervuert, 2009), pp. 79-112. 
criticise precisely this omission of awareness. So the fictional Catholic Kings can be seen at once as a model and a critical mirror for the contemporary king.

Lope de Vega wrote innumerable plays, and many of them can undoubtedly be characterised as completely orthodox. But the analysis of Fuenteovejuna has revealed that this fact should not be assumed for all his plays. On closer inspection, we rather detect that they are graded in shades of orthodoxy. Despite his fundamental agreement with the idea of social order, Lope remains a poly-contextural and critical author who maintains a certain distance from the centre of power. Fuenteovejuna in particular is replete with ambivalences that cannot be dissolved into a singular interpretation. In order to find a possible explanation for this complexity, we should first adjust our image of the historical context and second should consider the concrete circumstances of Lope's life.

Concerning the first point, it could be shown that seventeenth-century Spain is-despite of the prevailing Counter-Reformation culture and its censorship ${ }^{60}$-a polyphonic, internally differentiated configuration in which many contextures overlap. ${ }^{61}$ Concerning the second point, it is very likely that Lope's social provenance plays an important role in the empathy for the populace that he displays in Fuenteovejuna. Stemming from the same social rank himself and having traversed society from the bottom to the top, he perfectly knows the troubles the populace has to suffer. So even when living in the centre of power and agreeing (more or less) with the existing order, his experiences make him keep a certain internal distance which sharpens his eyes for current shortcomings and injustices. Besides this, his friendship with María de Zayas and others may have sensitised him to the problematic situation of women in an androcentric world. If in his play El Nuevo Mundo (The New World) he is not able to apply this critical posture to the problems of colonisation, ${ }^{62}$ this is not inconsistent. The colonies are too far away to inspire empathy. For this, the work of Sor Juana is necessary.

60 See Agustín de la Granja, “Comedias del Siglo de Oro censuradas por la Inquisición (Con noticia de un texto mal atribuido a Rojas Zorrilla),” in: Odette Gorsse and Frédéric Serralta, edd., El Siglo de Oro en escena: Homenaje a Marc Vitse (Toulouse: Presses Universitaires du Mirail, 2006), pp. 435-447.

61 For this concept of cultures as pluralistic configurations of overlapping contextures see Ventarola, Transkategoriale Philologie, chaps. 1-3, pp. 13-288.

62 For more information on this play see my following analysis. 


\section{Sor Juana Inés de la Cruz: Transcultural Criss-Crossings of Multi-Didactic Structures in El divino Narciso (1688)}

The Hispano-American theatre culture of the epoch is strongly influenced by metropolitan Spain. In the course of the colonisation, the autochthonous traditions of theatrical performance are almost completely suppressed and replaced by the Spanish cultural-ideological material. ${ }^{63}$ The playwrights adapt themselves to the aesthetic example of Lope, Calderón, Tirso de la Molina and others whose plays are not only imitated but also performed many times on Hispano-American stages. Even the currently prevailing social function of the theatre-to instil doctrine and teach political and religious dogma-is adopted..$^{64}$ Sor Juana, too, is part of this particular dynamic of cultural grafting. The Mexican playwright, a humbly born mestiza, who was first a protégé at the Viceregent's court and afterwards chose to enter the cloister, sometimes explicitly locates herself within this tradition. ${ }^{65}$

Like in the case of Lope, the scholarly community is divided. Since she often describes herself as a pupil of Lope, Calderón, Góngora or Quevedo, and since in her works she undoubtedly strives to instil doctrine, many scholars qualify her as a

63 An overview of the early history of the autochthonous and Hispano-American traditions of theatrical performance can be found in José Miguel Oviedo, Historia de la literatura hispanoamericana, 3 vols., $1^{\text {st }}$ ed., $5^{\text {th }}$ reimpr. (Madrid: Alianza, 2007), vol. 1: De los orígenes a la Emancipación, chaps. 1-5, pp. 30-279. See also Manuel Antonio Arango Linares, Contribución al estudio de la obra dramática de Sor Juana Inés de la Cruz (New York, NY: Peter Lang, 2000), pp. 43 ff.; Marie-Cécile Bénassy-Berling, Sor Juana Inés de la Cruz: Une femme de lettres exceptionelle. Mexique XVII siècle (Paris: Harmattan, 2010), chaps. 1-2, pp. 17-58; Luis Alberto Sánchez, "Barroco, renacentismo, gongorismo, culteranismo y su versión hispanoamericana: Notas sobre $E l$ Lunarejo," in: [Actas del] XVII Congreso del Instituto Internacional de Literatura Iberoamericana: Sesión de Madrid, 3 vols. (Madrid: Ed. Cultura Hispánica del Centro Iberoamericano de Cooperación, 1978), vol. 1: El Barroco en América, pp. 281-288.

64 See Arango Linares, Obra dramática de Sor Juana Inés de la Cruz, p. 61.

65 For the life of Sor Juana see her own account in her famous Respuesta a Sor Filotea de la Cruz [1691], in: Obras completas de Sor Juana Inés de la Cruz, ed. Alfonso Méndez Plancarte, 4 vols. (México/Buenos Aires: Fondo de Cultura Ecónomica, 1951-1957), vol. 4: Comedias, sainetes y prosa, ed. Alberto G. Salceda, pp. 440-475. See also José María de Cossío, “Observaciones sobre la vida y la obra de Sor Juana Inés de la Cruz,” in: de Cossío, Notas y estudios de crítica literaria: Letras españolas (Siglos XVI y XVII) (Madrid: Espasa-Calpe, 1970), pp. 243-284. For more details on the Mexican theatre of the seventeenth century see Humberto Maldonado Macías, "Introduction,” in: Maldonado Macías, ed., La teatralidad criolla del siglo XVII, Teatro mexicano: historia y dramaturgia 8 (México: Consejo Nacional para la Cultura y las Artes, 1992), pp. 11-47. 
mere imitator of (male) Spanish literature and its alleged doctrinal propaganda. ${ }^{66}$ The transcultural "exchange" would be reduced to a mere acculturation. Others pay more attention to the subtle transformations, reversals, transgressions and criss-crossings she stages within her texts and, therefore, highlight their subversive character, be it in a feminist and/or in an anti-colonial perspective. ${ }^{67} \mathrm{I}$ wish to propose another interpretation, an interpretation that makes it possible to harmonize the other readings and take into account my re-reading of Lope. I will show that Sor Juana not only transforms her imitation into a mimicry, which in postcolonial readings of her work plays an important role, ${ }^{68}$ but into an independent and constructive aemulatio, where the combination of analogies and differences is shaped in quite another manner. Whereas the mimicry is a strategy of survival of the powerless, the aemulatio is a sort of powerful imitation that strives to surpass the model. ${ }^{69}$ By deliberately continuing and even reinforcing

66 See for example Arango Linares, Obra dramática de Sor Juana Inés de la Cruz, pp. 62 ff., p. 201; Alexander A. Parker, "The Calderonian Sources of El divino Narciso by Sor Juana Inés de la Cruz," Romanistisches Jahrbuch 19 (1968), pp. 257-274; Ángel Valbuena Briones, Literatura hispanoamericana, $4^{\text {th }}$ ed. (Barcelona: Gili, 1969), p. 134; Wolfgang Zwack, "Indianische Religion und christlicher Opfergedanke: Das Zusammentreffen zweier Welten in der Loa zum Divino Narciso von Sor Juana Inés de la Cruz," in: Monika Bosse and André Stoll, edd., Theatrum mundi: Figuren der Barockästhetik in Spanien und Hispano-Amerika (Bielefeld: Aisthesis, 1997), pp. 191-214.

67 See for example Constance Wilkins, "Subversion through Comedy?: Two Plays by Sor Juana Inés de la Cruz and María de Zayas," in: Stoll et al., edd., Perception of Women in Spanish Theater, pp. 107-120; Stephanie Merrim, Early Modern Women's Writing and Sor Juana Inés de la Cruz (Liverpool: Liverpool University Press, 1999); Bernhard Teuber, “Curiositas et crudelitas: Das Unheimliche am Barock bei Góngora, Sor Juana Inés de la Cruz und José Lezama Lima,” in: Joachim Küpper and Friedrich Wolfzettel, edd., Diskurse des Barock: Dezentrierte oder rezentrierte Welt? (München: Fink, 2000), pp. 615-652; Verónica Grossi, Sigilosos v(u)elos epistemológicos en Sor Juana Inés de la Cruz (Madrid: Iberoamericana; Frankfurt a.M.: Vervuert, 2007); Félix Duque, "La hibridación de culturas en El divino Narciso," in: Wolfram Nitsch and Bernhard Teuber, edd., Zwischen dem Heiligen und dem Profanen: Religion, Mythologie, Weltlichkeit in der spanischen Literatur und Kultur der Frühen Neuzeit (München: Fink, 2008), pp. 311-328; Sebastian Neumeister, "Mimikry? Sor Juana als in-between der kolonialen Mythenaneignung," in: Nitsch et al., edd., Zwischen dem Heiligen und dem Profanen, pp. 329-343; Neumeister, "Disimulación y rebelión: El 'político silencio' de Sor Juana Inés de la Cruz," in: Kazimierz Sabik and Karolina Kumor, edd., La cultura del barroco español e iberoamericano y su contexto europeo (Warszawa: Instituto de Estudios Ibéricos e Iberoamericanos de la Universidad de Varsovia, 2010), pp. 229-239.

68 See especially the inspiring studies of Sebastian Neumeister quoted in the previous footnote. For Bhabha's concept of mimicry see Homi K. Bhabha, The Location of Culture (London/New York, NY: Routledge, 1994), chap. 4 ("Of Mimicry and Man: The Ambivalence of Colonial Discourse"), pp. 121-131.

69 Sor Juana herself draws attention to this strategy when in the Sainete Segundo of her play Los empeños de una casa she ironises an exaggerated admiration for the Spanish authors (vv. $36 \mathrm{ff}$.). 
the ambivalences of her Spanish model, Sor Juana not only teaches her compatriots, but also the Spanish colonisers themselves. She uses the possible multi-directionality of the drama in order to reverse and cross its didactic impact, and she does so with a special emphasis on transcultural communicative processes. The multi-didaxis of her play is also culturally differentiated. As an inhabitant of the New World, a mestiza and a woman, her distance from the metropolitan centre of power is much greater than Lope's, and this triple shifting of perspective allows her to develop new aesthetic and didactic concepts. ${ }^{70}$

Her religious play El divino Narciso (The Divine Narcissus) is a perfect example of this complex theatrical strategy. Composed around 1688, probably at the request of her patroness Vicereine María Luisa de Laguna, who in 1689 took it with her back to Spain for presentation there, the play was first published in Mexico in $1690 .{ }^{71}$ Many scholars consider it the most beautiful auto sacramental ever written in the Spanish language. ${ }^{72}$ In this play, the aforementioned combination of an overarching orthodoxy and local phenomena of irritation is realised in an exemplary manner. As an auto sacramental, El divino Narciso, at the highest level of meaning, is undoubtedly written in the service of religious education. ${ }^{73}$ Disguised in the integumentum of the Ovidian myth of Narcissus, the play performs the Passion of Jesus Christ: Narcissus appears as the allegorical personification of the Son of God; Echo epitomises the Devil; and the mirror image that Narcissus sees in the water and falls in love with represents creation and espe-

See Sor Juana Inés de la Cruz, Los empeños de una casa [1683]/ Amor es más laberinto [1689], ed. Celsa Carmen García Valdés (Madrid: Cátedra, 2010), pp. 107-299, pp. 231 ff.

70 With this perspective, I differ from common feminist and intersectional theories of feminine writing in the early modern period, as the prevailing interest of these studies is focused on the constraints the social situation of women brings about. See for example Bénassy-Berling, Sor Juana Inés de la Cruz, pp. 59 ff.; and, in more general terms, Ute Frackowiak, ed., Ein Raum zum Schreiben: Schreibende Frauen in Spanien vom 16. bis ins 20. Jahrhundert (Berlin: Edition Tranvía, Walter Frey, 1998). For the concept of intersectionality see Gabriele Winkler and Nina Degele, edd., Intersektionalität: Zur Analyse sozialer Ungleichheiten (Bielefeld: Transcript, 2009).

71 For the history of the text and its possible sources, see Arango Linares, Obra dramática de Sor Juana Inés de la Cruz, pp. 27ff.; Patricia A. Peters, “Introduction,” in: Sor Juana Inés de la Cruz, El Divino Narciso [1690]/ The Divine Narcissus, edd. and trans. Patricia A. Peters and Renée Domeier (Albuquerque, NM: University of New Mexico Press: 1998), pp. IX-XXXII, pp. XVII ff.

72 See the overview given by Arango Linares, Obra dramática de Sor Juana Inés de la Cruz, pp. $15 \mathrm{f}$.

73 For more details on the history and social functions of the auto sacramental see Küpper, Discursive Renovatio in Lope de Vega and Calderón, chap. 3; Miguel Ángel Pérez Priego, "Los autos: origen, evolución y adecuación ideológica,” in: Blecua et al., edd., El teatro del Siglo de Oro, pp. 397-421. 
cially humanity in general. With this setting, the audience learns the content of the Bible (the Eucharist in particular) in a playful, pleasurable way.

One special quality of Sor Juana's art of writing plays is the skilful interlacing of the plays themselves and their ancillary texts, be they prologues (loas), songs, interludes (sainetes) or choral-choreographed finales (saraos). El divino Narciso, too, is designed as a composite unit of the introductory loa and the following auto. ${ }^{74}$ Nevertheless, many scholars continue to analyse the loa and the auto as more or less separate entities. ${ }^{75}$ Patricia A. Peters even assumes that they could be performed separately. ${ }^{76}$ In fact, the complicated multi-didactical impulse of the play can only be appreciated when it is considered along with the introductory loa.

The loa already specifies the first addressee: it is the indigenous people of the Americas. Like Lope's play El Nuevo Mundo (The New World) and Calderon's play La Aurora en Copacabana (The Aurora in Copacabana), the loa performs (but now in an allegorical way) the first contact between the Spanish colonisers and the autochthonous population. ${ }^{77}$ In this fictional setting, the following auto sacramental is inserted as a second fictional world. The personification of Religion

74 Details on the Hispano-American history of the loa can be found in Anthony M. Pasquariello, “The Evolution of the Loa in Spanish America," Latin American Theatre Review 3.2 (1970), pp. 5-19; Humberto Maldonado Macías, "La evolución de la loa en la Nueva España: De González de Eslava a Sor Juana,” in: Ysla Campbell, ed., El escritor y la escena: Actas del I Congreso de la Asociación Internacional de Teatro Español y Novohispano de los Siglos de Oro (18-12 de marzo de 1992) (Ciudad Juárez: Universidad Autónoma de Ciudad Juárez, 1992), pp. 77-94.

75 See for example Celsa Carmen García Valdés, "Teatralidad barroca: las loas sacramentales de Sor Juana," in: Sara Poot Herrera, ed., Sor Juana y su mundo: una mirada actual (México: Universidad del Claustro de Sor Juana, Fondo de Cultura Económica, 1995), pp. 207-218; María Dolores Bravo Arriaga, "Las loas de los autos sacramentales de Sor Juana: Conciencia criolla y sentido de la composición," in: Serafín González and Lillian von der Walde, edd., Palabra crítica: Estudios en homenaje de José Amezcua (México: Universidad Autónoma Metropolitana, Fondo de Cultura Económica, 1997) pp. 250-259; Arango Linares, Obra dramática de Sor Juana Inés de la Cruz.

76 See Peters, “Introduction,” pp. XXIII.

77 For the above-mentioned plays by Calderón and Lope, see for example Küpper, "Teleologischer Universalismus und kommunitaristische Differenz: Überlegungen zu Calderóns La aurora en Copacabana, zu Voltaires Alzire, ou les Américains, zu Sepúlveda und Las Casas,” in: Karlheinz Stierle and Rainer Warning, edd., Das Ende: Figuren einer Denkform (München: Fink, 1996), pp. 435-466; Ingrid Simson, "La función de la alegoría en las comedias de temática Americana en el Siglo de Oro," in: Christoph Strosetzki, ed., Teatro español del Siglo de Oro: Teoría y práctica (Madrid: Iberoamericana; Frankfurt a.M.: Vervuert, 1998), pp. 305-321; Simson, Amerika in der spanischen Literatur des 'Siglo de Oro': Bericht, Inszenierung, Kritik (Frankfurt a.M.: Vervuert, 2003); Stephan Leopold, "La Victoria del telos o la ironía de la representation: tipología, legitimación y mestizaje en La aurora en Copacabana," in: Manfred Tietz and Gero Arnscheidt, edd., Calderón y el pensamiento ideológico y cultural de su época: XIV Coloquio Anglogermano sobre Calderón, Heidelberg, 24-28 de julio de 2005 (Stuttgart: Steiner, 2008), pp. 317-336. For 
appears as an intradiegetical narrator who speaks to the personification of the Americas and explicitly announces the following play as an instrument deployed in the service of the Mission:

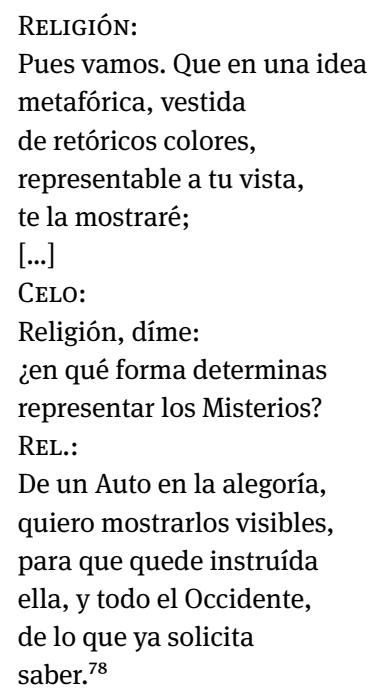

[RELIGION: Then come along with me, and I / shall make for you a metaphor, / a concept clothed in rhetoric / so colorful that what I show / to you, your eyes will clearly see; / [...]. / ZEAL: Religion, answer me: / what metaphor will you employ / to represent these mysteries? / REL.: An auto will make visible / through allegory images / of what America must learn / and Occident implores to know / about the questions that now burn / within him so.]

This duplication of fictional worlds is very skilful, because now the "real" inhabitants of the Americas can identify themselves with the intradiagetical audience of the loa and therefore become the first addressee.

But a closer look quickly reveals the innumerable modifications, reversals and transgressions Sor Juana has inserted into this overarching doctrinal pattern. The whole text is loaded with local phenomena or substages where she develops innovative and even utopian thoughts (and aesthetic structures); and it is especially with these heterotopian substructures that she strives to invert the traditional direction of didaxis and to advise the aesthetic and cultural colonisers themselves.

more differences between Lope and Calderón on the one hand and Sor Juana on the other, see my following analysis.

78 Sor Juana Inés de la Cruz, El divino Narciso, Loa, vv. 401-405; vv. 415-423. All references to El divino Narciso and quotations from the English translation are from Sor Juana Inés de la Cruz, $E l$ Divino Narciso/ The Divine Narcissus, trans. and edd. Peters and Domeier. 
Let me first focus on the central auto. Here, Sor Juana obtains the desired effect above all by multiplying the superimposed frames of reference. Not only is she merging the Greek myth and the biblical Passion, ${ }^{79}$ but she also inserts elements of ancient and medieval love lyric as well as of the psychomachian tradition. ${ }^{80}$ In addition to that, she merges narrativity and theatrical performativity. In each scene, another allegorical personification appears as an intradiegetical narrator, who explains and comments on the performed events. In this way, the whole fictional world of the auto is fashioned as a poly-contextural and poly-perspectival world. I can by no means demonstrate all the aesthetic and philosophical complexions that are brought about by these superimpositions, so I wish to concentrate on two aspects.

First, the conception of God. By merging the various textual traditions, the Passion of Jesus Christ is re-interpreted as a love story that, at the same time, explores and visualises the deepest inner conflicts of God himself. Narcissus/God is depicted as a very worldly lover of his mirror image (Nature) who sings love lyrics $^{81}$ and is, himself, subjugated to the laws of love:

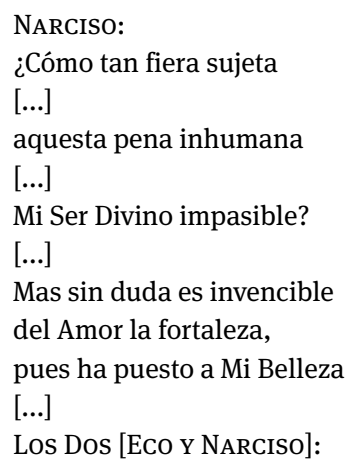

79 For this rhetorical strategy, which is usual in the religious plays of the Siglo de Oro, see Gloria D. Calhoun, "Un triángulo mitológico, idólatra y cristiano en El divino Narciso de Sor Juana," Ábside 34 (1970), pp. 373-401; Jean Krynen, "Mito y teología en El divino Narciso de Sor Juana Inés de la Cruz," in: Carlos Horacio Magis, ed., Actas del Tercer Congreso Internacional de Hispanistas (México: El Colegio de México, 1970), pp. 501-505; Arango Linares, Obra dramática de Sor Juana Inés de la Cruz, pp. 27 ff., pp. 37 ff., pp. 182 ff.; García Valdés, "La Biblia en la obra literaria de Sor Juana Inés de la Cruz,” in: Ignacio Arellano and Ruth Fine, edd., La Biblia en la literatura del Siglo de Oro (Madrid: Iberoamericana; Frankfurt a.M.: Vervuert, 2010), pp. 167-189. 80 For the complicated intertextual network of the play which forms "un maravilloso mosaico de formas poéticas y métricas," see Octavio Paz, Sor Juana Inés de la Cruz o Las trampas de la fe (México: Fondo de Cultura Económica, 1982), p. 464; Grossi, Sigilosos v(u)elos epistemológicos, pp. $133 \mathrm{ff}$. 81 See for example Sor Juana Inés de la Cruz, El divino Narciso, Auto, vv. 1136-1236, vv. 1447 ff. 
Sujeta, Humana, Pasible. ${ }^{82}$

[NARcissus: Why am I so cruelly subject / [...] / to that torture, so inhuman / [...] / though divine, invulnerable? / [...] / But without doubt, invincible / is love in its great potency / since it has made My loveliness / [...] / THE Two (ЕсHO AND NARCIssus): Subject, Human, Vulnerable.]

By highlighting the humanity, the inner conflicts and even the erotic emotionalism of God, Sor Juana is subtly modifying the Counter-Reformation conception of the Highest Being. ${ }^{83}$ She clearly anticipates a critique of the Christian doctrine that a few years later she will develop in detail in her famous Carta atenagórica (Letter Worthy of Athena), which brought her a complete prohibition of writing. ${ }^{84}$

The second aspect concerns the aesthetics of the text. By merging the various textual traditions and by mingling narrativity and performativity, Sor Juana is exploring new forms of allegorical writing and even of textuality in general. Every allegorical protagonist of the text fulfils several functions that in the course of the play are always shifting. In addition to that, Sor Juana inserts one textual layer into the other and does so continuously, very much like a Russian doll effect. So the text becomes a multilevelled universe, where the semantic layers and meanings form ever-changing constellations. And what is more: as all the allegorical personifications can also appear as explaining and commenting narrators, they are at the same time meta-allegorical allegories. Eco, for example, not only stands for the Devil and for human sin (on the psychomachian level of the text), ${ }^{85}$ but Sor Juana also introduces the following scene and explains the logic of allegorical integumentum in general:

Eco:

[...]

escuchadme. Ya habéis visto

82 Vv. 1501-1510. See also vv. 1471 ff., vv. 1491 ff., vv. 1522 ff., vv. 1533 ff.

$83 \mathrm{In} \mathrm{vv} 596 \mathrm{ff}$. of the auto, Sor Juana explicitly names the debates of the Council of Trent. Her ludic transformation of Christian dogma goes even further. In vv. 950 f., Naturaleza (who epitomizes nature as well as the human nature of God) reveals that she is "negra" ("[...] aunque soy negra, soy hermosa, / pues parezco a Tu imagen milagrosa” [“[...] though black, yet I am fair / because your countenance I bear"]), and in vv. $1060 \mathrm{ff}$. the whole myth of Diana is realised with inverted sexual roles.

84 See Sor Juana Inés de la Cruz, Carta atenagórica [1690], in: Obras completas de Sor Juana Inés de la Cruz, vol. 4, pp. 412-439. Details on the text and on the impact it had on Sor Juana's life can be found in Paz, Sor Juana, pp. 524-533; Dario Puccini, Una mujer en soledad: Sor Juana Inés de la Cruz, una excepción en la cultura y la literatura barroca [Una donna in solitudine, 1996], trans. Esther Benítez (Madrid: Anaya \& Muchnik, 1996), pp. 29-38.

85 See for example her dense monologue in vv. 295-526 of the auto. 


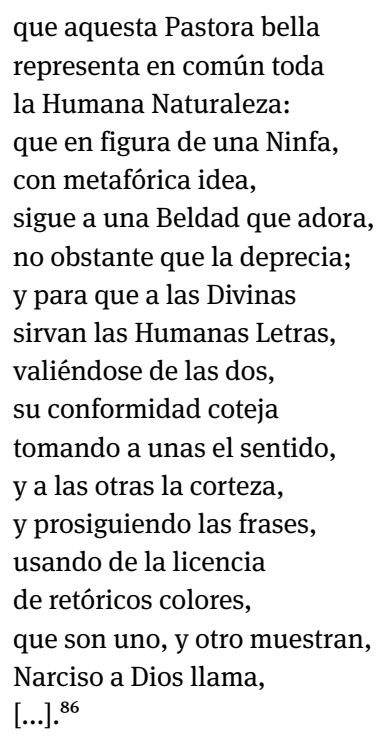

[EсHO: (...) Now listen. You already know / that this lovely shepherdess / stands for the commonality / of Human Nature; and that she, / clad in the costume of a nymph, / (I now speak metaphorically), / pursues a beauty she adores, / who nonetheless despises her; / and so that human poetry / might minister to Holy Writ, / she takes some elements from both, / combining them where they agree, / abstracting meaning from the one, / and from the other taking form; / and with poetic license, she / composes sentences of such / iridescent rhetoric / that what they seem, they never mean; / therefore, she calls Narcissus God, (...).]

Through this device, the referential and the self-referential dimension of literature, didaxis, and an autonomous aesthetic play are perfectly harmonised.

If we consider the loa, we can grasp the complex multi-didactical aim of these innovations. As I previously mentioned, the loa broadens the cultural focus by explicitly inserting the indigenous population. When doing so, Sor Juana also modifies her models. In an astute analysis of Calderón's Aurora in Copacabana, Joachim Küpper has recently shown that in the play the first contact scene reproduces all the problematic arguments that in the colonial epoch are deployed in order to legitimise the cruelties of Christian colonisation. ${ }^{87}$ In the figural scheme, all cultural differences are completely neglected and reduced to a relationship of inferiority and superiority. ${ }^{88}$ In this way, the conquerors appear as redeemers who help the "poor" indigenous people to establish a social order and to save

86 Sor Juana Inés de la Cruz, El divino Narciso, Auto, vv. 322-340. See also vv. 322 ff.; vv. 1343 ff. 87 See Küpper, “Teleologischer Universalismus,” pp. 434-466.

88 Pp. 442 ff. 
their souls. ${ }^{89}$ The same critique can be expressed with regard to Lope's play $E l$ Nuevo Mundo. ${ }^{90}$ I would add that this conception also determines the strategies of missionary didaxis that are realised. In both plays, the indigenous people are not converted by means of rational explanations but by deploying dazzling stage machinery that produces the illusion of divine miracles. ${ }^{91}$ They are not convinced, they are subjected.

The first contact scene of Sor Juana's loa strongly differs from that. It is true that, like the others, it culminates in a praise of the religious superimposition. ${ }^{92}$ But, at the same time, Sor Juana is criticising all the aforementioned arguments. First, she highlights the cultural differences and even the value of the indigenous culture by staging a real Indian rite and not only Western clichés about the Indians, as Lope and Calderón did. ${ }^{93}$ Second, she at least reduces the cultural hierarchy by emphasising the "barbarian" elements of the Christian religion, namely the fact that even the Christian faithful eat their God:

\author{
AMÉRICA: \\ ¿[S]erá esa Deidad que pintas, \\ $\tan$ amorosa, que quiera \\ ofrecérseme en comida, \\ como Aquésta que yo adoro? \\ [...] \\ OCCIDENTE: \\ ¡Vamos, que ya mi agonía \\ quiere ver cómo es el Dios \\ que me han de dar en comida,
}

89 Pp. 447 ff.

90 See for example Lope de Vega, El nuevo mundo descubierto por Cristóbal Colón [1614], edd. Jean Lemartinel and Charles Minguet (Lille: Presses Universitaires de Lille, 1980), vv. 1439-1448; vv. 2020 ff.; vv. 2510 ff. An analysis of the play can be found in Simson, "La función de la alegoría."

91 See for example Lope de Vega, El nuevo mundo, vv. 1744 ff.; Pedro Calderón de la Barca, La aurora en Copacabana [1672], in: Obras completas de Calderón de la Barca, ed. Ángel Valbuena Briones, 3 vols. (Madrid: Aguilar, 1987), vol. 2, pp. 1315-1361, vv. 594-692. The use of dazzling stage machinery and emotional images was current in the Siglo de Oro. See for example John Earl Varey, "Scenes, Machines and the Theatrical Experience in Seventeenth-Century Spain," in: Antoine Schnapper, ed., La scenografia barocca/La scénographie baroque/ Stage Design during the Baroque (Bologna: Ed. Clueb, 1982), pp. 51-63; Antonio Azaustre Galiana, "Recursos retóricos en el teatro del siglo de oro: El caso de la 'evidentia'," in: Blecua et al., edd., El teatro del Siglo de Oro, pp. 29-49.

92 See Sor Juana Inés de la Cruz, El divino Narciso, Loa, vv. 261 ff., vv. 280 ff.

$93 \mathrm{Vv}$. 1-72. The rhetorical strategy of the Spanish playwrights to transform the Indians into Spaniards is shown in detail by Simson, Amerika in der spanischen Literatur, pp. 289-320. 


\author{
(Cantan la América y el Occidente y \\ el Celo:) \\ diciendo que ya \\ conocen las Indias \\ al que el Verdadero \\ Dios de la Semillas! ${ }^{94}$
}
[AMERICA: (B)ut would the God that you reveal / offer Himself so lovingly / transformed for me into a meal / as does the god that I adore? / (...) / OccIDENT: Let's go, for anxiously I long to see / exactly how this God of yours / will give Himself as food to me. / (America, Occident and Zeal sing:) The Indies know / (...) / who is the true / God of the Seeds.]

Third, she criticises all the cruelties of the Christian colonisation by showing the persecution on stage. ${ }^{95}$ Fourth, she enhances the role of women by fashioning the female allegories ("Religión" and "América") as the spokespersons of the whole loa. ${ }^{96}$ Last but not least, she stages completely different strategies of missionary didaxis: instead of using dazzling stage machinery and unconscious manipulations by means of emotional images, the allegory of Religion appeals to reason. Like the other intradiegetical narrators of the play, she constantly explains her strategies and the functioning of the allegories deployed. ${ }^{97}$ In the play, this self-referential dimension culminates in a questioning of the audience: when Eco evokes the following auto as a place of God's real presence, she at the same time requests her audience to judge whether the device is successful:

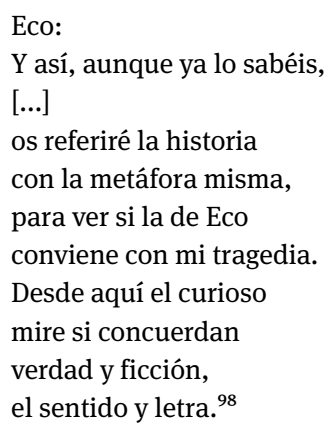

94 Sor Juana Inés de la Cruz, El divino Narciso, Loa, vv. 370-373, vv. 486-492.

95 Vv. $185 \mathrm{ff}$. Besides this scene, the allegory of America explicitly tries to inspire empathy for the Indians (vv. 175 ff.) and criticises the use of brutal power (vv. 91-95, vv. 206 ff.).

96 The presence of the male allegories ("Occidente" and "Celo") is reduced to a few short replies. 97 See for example Loa, vv. 401 ff., vv. 418 ff., vv. 462 ff.; Auto, vv. 112 ff., vv. 133 ff., vv. 140 ff., vv. $322 \mathrm{ff} .$, vv. $1044 \mathrm{ff}$.

98 Auto, v. 362, vv. 366-373. 
[EсHо: And though you may already guess / my story [...] / still I will tell it to you now, / using the self-same metaphor / so you can judge if Echo's tale / echoes the tale I told before. / From that, the curious might reflect / upon the possible accord / between these fictions and the truth, / between significance and word.]

By textually superimposing the theatrical strategies of persuasion with their self-referential naming, religious education and its critical assessment are perfectly harmonised. In addition to this, Sor Juana demonstrates possible new ways of using emotions, and here the other modifications of the auto come into play. By humanising God as a worldly lover of humanity, the violent elements of the stipulated conversion are exchanged for an appeal to return God's love.

In order to complete the new interpretation, we must focus again on the intended addressee of the play. In verses $443 \mathrm{ff}$. of the loa, the personification of missionary zeal hints at the fact that Sor Juana has written her play to be performed not only in the Hispano-American colonies, but above all in the Spanish capital, Madrid: "CELo: ¿Pues no ves la impropiedad / de que en Méjico se escriba / y en Madrid se represente?"99 ["ZEAL: That you should write in Mexico / for royal patrons don't you see / to be an impropriety?"]

With this statement, he explicitly indicates that Sor Juana is constructing a gap between the internal and the external communication of the play. In the fictional world of the loa, the addressees are the Indians; but on the outside the play is also aimed at the Spaniards themselves. This differentiation reveals that Sor Juana deliberately strives to culturally diversify the teachings of her text. By informing the Indians about the Eucharist, the orthodox function of an auto sacramental is undoubtedly fulfilled, even though in a very new interpretation of this Eucharist and by means of very new didactic and aesthetic devices. And, precisely through these innovations, Sor Juana also strives to teach the colonisers themselves-the political leaders as well as the playwrights. By demonstrating the cruelty of cultural and religious superimposition on stage, the conquerors are requested to relativise their own standpoint. Sor Juana obviously tries to set in motion a process of self-reflection and self-critique in the minds of her Spanish audience. At the same time, she provides alternative educational options, which anticipate the early enlightenment. The power of reason is enhanced and the religious emotions are addressed in an innovative way. Even women can find new role models-in the female allegories which (much as in Lope's play) are portrayed as strong, eloquent and interventionist characters. And with her innovative concepts of theatrical and allegorical textuality, with her perfect reconciliation of didaxis and aesthetics, she is appealing to the playwrights of the whole

99 Loa, vv. 443-445. 
world. Her Divine Narcissus can be seen as a manifesto of a new art of writing plays, which is at least as innovative as Lope's was. With her independent and constructive "imitation" of the Spanish model, Sor Juana is realising a kind of "writing back" that is free of violence and deeply innovative at once. And with this, I come to my conclusion.

\section{Conclusion}

The comparison of Lope and Sor Juana has, as I hope, demonstrated that binaristic theoretical patterns do not suffice to describe the complexity of colonial interchange, especially in the case of the relationship between Spain and Hispano-America. Only when we consider the poly-contexturality and the multi-didactical impulse of the authors are we able to grasp the peculiarity of each play as well as of the cultural dialogue between them. It could be shown that both playwrights use a multi-didaxis in order to realise both a propagandistic affirmation and a critical analysis of the central tenets of their (social and religious) contexts. In conformity with their respective cultural and social location, only the weighting differs. Lope remains inside the borders of Spanish culture and plays with social hierarchy. Sor Juana extends the critical multi-didaxis to the hierarchy of cultures. And because of her distance from metropolitan Spain, she can even try to establish a new cultural centre. By taking into account this fact, the simplifying logic of actio and reactio, of cultural grafting and "writing back," is substituted by a more complex model which takes into account the entanglement of analogies and differences as well as the graded shading of cultural belonging. If we conceive the theatre as a mass medium and an organon of subjectivisation, we must say that both playwrights are able to individualise their audience to an extent that until now has mostly been neglected. As they are tied to the baroque context, they still do not stage revolutionary processes in the radical sense. But their texts are-to an ever changing extent-replete with heterotopian phenomena which at least hint at the possibility of new social and aesthetic orders. 